\title{
Hidden in Bones: Tracking the Hyksos across the Levant
}

\author{
by Nina Maaranen ${ }^{1}$, Holger Schutkowski ${ }^{2}$, Sonia Zakrzewski ${ }^{3}$
}

\begin{abstract}
Though the term Hyksos commonly refers to the rulers of the Egyptian Second Intermediate Period, it is also used to describe the larger population from which these rulers derived. Archaeological, artistic and textual sources suggest a Levantine origin of the 'Hyksos people'; however, whether this was a single homogenous group or several groups from a wider area has remained uncertain.

Non-metric traits, also called epigenetic traits, are normal variations of the human skeleton. The traits, though seemingly random in a single person, often have a genetic component that links biologically closely related people together, enabling an exploration of biological affiliations not only within but also between populations.

As a non-invasive method, non-metric trait analysis can be used to study biological closeness when there is no wish or possibility to use DNA analysis. An increasing number of non-metric trait analyses is being conducted on human skeletal remains, creating trait distribution maps for a wider exploration of biological closeness. As part of the Hyksos Enigma Project, non-metric traits from human skeletal remains from Tell el-Dab'a, the ancient Hyksos capital of Avaris, are recorded. The results help to understand familial relationships within the site but also compare the site and its subgroups to Levantine sites, potentially offering new insight into the Hyksos origin and the wider migration of people in the Levantine area.
\end{abstract}

\section{Introduction}

The weakening and eventual dispersion of central government at/towards the end of the Middle Kingdom left a vacuum to be filled by regional power centres. ${ }^{4}$ In the eastern Delta, the Second Intermediate Period was marked by the rise of the $15^{\text {th }}$ Dynasty and the so-called Hyksos rulers. The term is believed to derive from the ancient Egyptian Hq3-h3swt, rulers of foreign lands. ${ }^{5}$ According to the Hellenistic historian Manetho, as recounted and repeated by later historians and scholars, the Hyksos were a group of foreign invaders, able to

1 Bournemouth University, nmaaranen@bournemouth. ac.uk

2 Bournemouth University, hschutkowski@bournemouth. ac.uk

3 University of Southampton, S.R.Zakrzewski@soton. ac.uk

4 Bader 2008; Bourriau 2010, 11.

5 First translated by GrifFith 1897, 297. overthrow the Egyptian rule. ${ }^{6}$ The Roman historian Josephus referred to the Hyksos as 'Shepherd kings', not only speculating on the etymology of the term but also generating an ethnic denominator by identifying the described Hyksos exile with the Israelite Exodus. ${ }^{7}$ Not all early historians shared this interpretation, as evident from the accounts of Africanus and Eusebius, who were leaning towards a Phoenician origin instead. ${ }^{8}$

The contradictions even in the earliest accounts exemplify the loss of actual information regarding the Hyksos and thus sent modern scholars into vastly different directions when looking into the origin of the Hyksos rulers. While the Hyksos have sometimes been assigned with specific ethnic affiliations, such as Hurrians, ${ }^{9}$ Amorites ${ }^{10}$ and Israelites ${ }^{11}$ more generic descriptors have also been used. ${ }^{12}$ Early analyses on material culture led Engberg to propose a connection between the Hyksos and the Levantine area, ${ }^{13}$ which was further strengthened after the discovery of the Hyksos capital of Avaris. The first stela of Kamose refers to the king of Avaris and his people as Aamu, Asiatics ${ }^{14}$ while the second adds the nominator 'ruler of Retenu' in the town of Avaris. ${ }^{15}$ During the Middle Kingdom, Retenu is believed to have referred to the Levantine coast ${ }^{16}$ however, the ancient sources do not mention an exact origin, and current analyses on the material and textual evidence have generated compelling arguments for both northern and southern Levantine origins. ${ }^{17}$

6 Manetho's Aegyptiaca, Frg. 42: 1.75-76, translated by WADDELL 1940, 78-79.

7 WADDELL 1940, 87-89.

8 WADDELL 1940, 90-97.

9 Beckerath 1964; Engberg 1939; Helck 1971; Ward 1961.

10 Alt 1954.

11 Popular especially among early scholars, e.g., see PETRIE 1906.

12 Maspero 1903; Tomkins 1890.

13 Engberg 1939; VAn Seters 1966, 1-4 criticized his work for referring to Levantine material culture as Hyksos, causing confusion in later analyses. Several researchers took up the habit; e.g., see the description by SCHAEFFER (1962) on Hyksos tombs from Ugarit.

14 First translation by GARDINER 1916.

15 Stela translated by НАвасHI 1972.

16 Inscriptions found near mines at Serabit el-Khadim in Sinai tell of the employment of Retenu Asiatics in mining expeditions especially during the reign of Amenemhat III in the $12^{\text {th }}$ Dynasty, c. 1844-1797 BCE (BIETAK 1996, 19; see GARDINER et al. 1955, 206 for translation).

17 Ben-Tor 2007; 2010; Bietak 2010; Kopetzky 2012. 
Egypt had trade relations with the Levantine coast from at least the Old Kingdom onwards, ${ }^{18}$ although material culture suggests an even earlier relationship between the areas. ${ }^{19}$ The evidence of Asiatics in Egypt appears to increase substantially during the Middle Kingdom, such as the appearance of the term Aamu, ${ }^{20}$ documentary and archaeological sources alluding to assimilated Asiatic workforces, ${ }^{21}$ iconographic depictions of Asiatics in private tombs ${ }^{22}$ and so on. The origin, or more likely origins, of these people leads to a more complex question of the Hyksos identity and whether the term 'Hyksos' masks underlying diversity. Migration has been called "a key constituent element of human life in virtually all periods", ${ }^{23}$ which has socioeconomic implications not only for the migrating group but for the communities losing and receiving people. ${ }^{24}$ In regions where textual evidence has been abundant, mobility and migration studies have played a minor role; ${ }^{25}$ however, written sources are challenging, as they may be misleading, both intentionally and unintentionally. In the case of the Hyksos, there is little available textual evidence produced by the rulers themselves. Instead, the majority of written sources are part of the ancient Egyptian rhetoric with very specific topoi for foreigners. ${ }^{26}$

After a brief absence due to criticism concerning the lack of dimensionality, migration and mobility, studies have returned to archaeology. This 'awakening' has been attested to by the developments in bioanthropological techniques, ${ }^{27}$ though the abating of the processual framework in archaeology is also key. Biodistance, which measures the physical similarity of organisms, was the focus of most skeletal biological research during the $19^{\text {th }}$ century but was plagued by

18 Asiatics have been depicted on sea-going ships to and from the Levant in the Old Kingdom relief from the pyramid complex of Sahure (BIETAK 2007, fig. 29.1).

19 For further details and references, see BietaK 2007, 417.

20 According to BIETAK 2007, 421, the term was used to describe Western Asiatics from at least the $12^{\text {th }}$ Dynasty onwards.

21 In the Illahun papyri, the $A a m u$ resided near the $12^{\text {th }}$ Dynasty capital Itjtawy, near modern el-Lisht, at a place called wenut, working in low-ranking professions (Bietak 2007, 421; Posener 1957, 152; Luft 1992). Tell el-Dab a shows the continuous presence of Egyptianized Asiatics since the $12^{\text {th }}$ Dynasty (BIETAK 2010, 139).

22 Texts and drawings from the Beni Hassan tombs first published by Newberry 1893. See pl. XXXL for a depiction of the Aamu people.

23 Greenblatt 2010, i.

24 Bader 2012; Kelly 1992.

25 Dommelen 2014.

26 In Egyptian ideology, the ritual killing of the 'vile foreigners' was part of the stately topos (see LopriENO 1988). Some say research has not always considered the implications of propaganda enough (LEPROHON 2014, 309-311; RYноLт 1997, 147-149).

27 Burmeister 2000; Dommelen 2014; Kelly 1992. racial stereotypes. The field has since taken leaps both theoretically and methodologically, ${ }^{28}$ and biodistance methods are currently used to assess biological variation both between and within sites. ${ }^{29}$ Dental nonmetric traits have been a part of this development. Here, a brief overview is presented of the development of the field and the attitudes that shaped it, to elaborate how dental non-metric trait analysis has taken its current form.

\section{From Race to Ethnogenesis: Changing Frameworks in Migration Studies}

Biological distance, or biodistance, is traditionally based on phenetics, the classification of organisms according to their morphological similarity, and rests on the assumption that physical appearance is, at least to some extent, an indicator of biological affinity. ${ }^{30}$ The early history of biodistance analyses was strongly influenced by racial descriptors, visible also in the archaeological studies utilizing the techniques.

Linnaeus introduced a classification system based on observable characteristics that continues to form the basis of taxonomy. ${ }^{31} \mathrm{He}$ extended his classification of plants and animals to humans, dividing the species into subclasses, which formed the basis of 'races' that continue to persist in everyday vernacular. The initial subclassification followed geographic regions, but later the inclusion of behavioural traits took the groupings even further from a morphological basis. ${ }^{32}$

The interest in human origin was heavily infused with the desire to rank the Linnaean taxa. ${ }^{33}$ Even when Darwinian Theory was introduced, the prior perception drove the analysis to regard phylogenies though ranking with little attention to biological functionality and significance. ${ }^{34}$ The misconception that race forms a meaningful biological classification and has any implications to the 'production of civilization', has been called an 'original sin' of anthropology. ${ }^{35}$

28 Buikstra et al. 1990. The use of races and racial stereotypes has been a major influencer in archaeological and bioanthropological research, which is why a further theoretical account is presented below.

29 ZAKRZEWSKI 2007.

30 Hefner et al. 2016, 3.

31 Linnaeus 1735; 1758. The cladistic system may have been inspired by family trees used across Europe by the $16^{\text {th }}$ century to exhibit genealogy (CONNERTON 1989).

32 Though the Linnaean approach was not the only one, it became the consensus. E.g., MARKs (1995) has criticized Linnaeus for being more interested in humors than in physical differences when regarding humans. Linnaeus's ideas were further envisioned by BLumENBACH 1775, the first to refer to five races.

33 Blumenbach 1775; Morton 1844.

34 Armelagos et al. 1982.

35 Levi-Strauss 1952, 1-3. 
Alongside racial classification, a culture-historical approach dominated archaeological theory, producing similar, descriptive analyses of cultures. The backdrop of these theoretical frameworks was the rise of the nationalistic movement, which did not begin to decline until the end of WWII. ${ }^{36}$ The long-held idea of associating material assemblages with archaeological cultures, ${ }^{37}$ a view that developed alongside linguistic and racial typologies, was being questioned by new emerging methodological and theoretical approaches. ${ }^{38}$ The processualist criticism of the culture-historical view ultimately led to a temporary abandonment of migration studies, ${ }^{39}$ focusing on explaining culture as an adaptation mechanism. ${ }^{40}$

The shift in the archaeological approach to the past coincided with the emergence of bioarchaeology, a bioanthropological framework that considers the dynamic relationship of human culture and the surrounding social, political, economic and ecological environment. ${ }^{41}$ The paradigm shift began with Washburn, who rejected the previous 'religion of taxonomy' and demanded for hypothesis testing and a holistic consideration of human remains. ${ }^{42}$ As a result, studies turned away from descriptions and race classifications, and towards functional morphology where physical changes formed a part of a dynamic process. ${ }^{43}$ Studies concerning inter-site population biodistance in the English-speaking world began to decline. ${ }^{44}$ Instead, focus was directed towards understanding evolutionary pathways and formulating interpretations combining biological, socio-cultural and environmental factors. ${ }^{45}$

At the abating of processualism, migration returned to archaeology and was able to acquire models from the other social sciences that had maintained interest in the topic. ${ }^{46}$ Ethnographic studies were used to generate models of migration and mobility, ${ }^{47}$ giving tools to distinguish patterns left by different types of movement through the environment. Kinship studies had expanded beyond biological models of group

36 Hakenbeck 2008; Trigger 2006, 241-250.

37 Childe 1925; 1950; 1958; inspired by Kossinna 1911.

38 Binford 1965; WiLley and PHILlips 1958.

39 Adams 1968; Adams et al. 1978; Myhre and Myhre 1972.

40 Burmeister 2000. Though valid as one mode of change, the replacement of migration solely with adaptation made AnTHONY 1990 describe the effect as 'throwing the baby out with the bathwater'. Currently, the two approaches are seen as parts of a greater dynamic process.

41 Buikstra 1977; Clark 1972; Larsen 1987; 1997; Levins and Lewotin 1985; Stinson et al. 2012; ZucKerman et al. 2012.

42 Mikels-Carrasco 2012; Washburn 1951; 1953.

43 Armelagos and Van Gerven 2003.

44 Buikstra et al. 1990.

45 Armelagos and Van Gerven 2003; Johnson and Paul 2013.

46 Burmeister 2000; Dommelen 2014; Kelly 1992.

47 Anthony 1990; Burmeister 2000; Hakenbeck 2008. formation as a response to criticism on their normative Eurocentric conceptions of relatedness. ${ }^{48}$ Ethnogenesis, 'the establishment of group distinctiveness', ${ }^{49}$ studies the ways group identity can be formed through phenomena such as class, ethnicity, community, nationality, religion or political affiliation..$^{50}$ In this new framework, biodistance analyses are no longer the driving force of the investigation but a tool among others for understanding the dynamics of past communities. According to the concept of ethnogenesis, a group can only be considered as a cladistic entity when it is homogenous not only physically but also culturally and linguistically.

\section{Biodistance Analysis Using Teeth}

Recent advances in bioarchaeological and biogeographical methods using isotope, DNA and biodistance analyses have altered views on migration and continuity in past societies, ${ }^{51}$ raising new questions about the nature of migration itself and its role in society. ${ }^{52}$ Ancient DNA analysis can be used to investigate both individuals and populations, while isotope analysis can provide a proxy for individual mobility. ${ }^{53}$ However, there may be practical and potential ethical issues with sampling human remains from several politically divergent regions for destructive analyses. ${ }^{54}$ As a result, non-destructive, morphology-based biodistance analysis has maintained its value as a mode of investigation.

The German anthropologist Georg Buschan was the first to use the term 'dental anthropology' in the beginning of the $20^{\text {th }}$ century, ${ }^{55}$ though interest in tooth characteristics had developed well before (see Tab. 1). Following the overall theoretical development of the field, dental anthropology studies have transformed from descriptions of morphological characteristics and metrics to using standardized methodology and multifactorial statistical analyses that play into a larger question of the individuals and groups under analysis. In addition to biodistance, teeth can be used to investigate aspects such as functionality, health, evolution, growth and usage. ${ }^{56}$

48 Collier and Yanagisako 1987; Johnson and Paul 2013; MacCormack and Strathern 1980; Schneider 1972; 1984.

49 Sturtevant 1971, 92.

50 StoJanowsKi 2013.

51 E.g., see the recent publication on Middle Bronze Age Canaanites from Sidon by HABER et al. 2017.

52 Cameron 2013; Linden 2007.

53 Hawass et al. 2010; 2012; Keller et al. 2012; SCHUTKOWSKI et al. 2001; SchutKowski and Ogden 2011; SoŁtysiak and SCHUTKOWSKi 2015; ZinK et al. 2003.

54 Killgrove 2013.

55 SCott and Turner 1988.

56 SCott and Turner 1988. 
The current standard for evaluation of dental nonmetric trait variation is the Arizona State University Dental Anthropology System (ASUDAS). ${ }^{57}$ It is an expansion of the work begun with Dahlberg, who wished to standardize scoring between observers. ${ }^{58}$ Although the number of traits in the ASUDAS is not nearly as high as the total number of traits available, the ones included in the system have been selected due to their reliability (full list in Tab. 2). They are characterized by durability against (moderate) surface destruction, easy identification, high recording repeatability, strong genetic links and a lack of sexual dimorphism. ${ }^{59}$
Traits are recorded either as present/absent or as a grade from absent to full expression. Generally, only one member of the tooth type (incisor, canine, premolar, molar) is carried over to the final analysis due to the correlation within tooth classes as well as the subsequent redundancy of information. ${ }^{60}$ Furthermore, only one tooth from either the right or left side of the dental arcade is selected per individual to avoid duplication and skewing of data. Some have chosen a side prior to observation, ${ }^{61}$ but the more usual practice is to choose the tooth with the most visible expression. ${ }^{62}$

\begin{tabular}{|c|c|}
\hline Reference & Description \\
\hline Von CARABelli 1842 & The publication includes the first description of the Carabelli cusp \\
\hline OWEN 1845 & Comparative work on the dentition of fish, reptiles and mammals \\
\hline Azoulay and Regnault 1893 & Comparative work on primate incisors with a strong racial undertone \\
\hline THOMPSON 1903 & $\begin{array}{l}\text { An analysis on the teeth of 'Inca Peruvians' that led to the recognition of } \\
\text { population variability in subsequent studies }\end{array}$ \\
\hline HRDLIČKA 1920; 1921 & $\begin{array}{l}\text { First comprehensive descriptions of non-metric traits, such as the shov- } \\
\text { el-shaped incisors }\end{array}$ \\
\hline LASKER 1945 & $\begin{array}{l}\text { This study on dentition from China and Chinese immigrants in the United } \\
\text { States was part of the genetic foundation of dental morphology }\end{array}$ \\
\hline DAHLBERG $1951 ; 1956$ & $\begin{array}{l}\text { First large leap in the standardization of trait recording and the creation } \\
\text { of casts }\end{array}$ \\
\hline HANIHARA $1954 ; 1955$ & Dental non-metric traits for deciduous teeth \\
\hline Sсотт 1973 & $\begin{array}{l}\text { Seminal work analysing the relationship between dental morphology and } \\
\text { genetics among indigenous American populations }\end{array}$ \\
\hline Nichol 1990 & $\begin{array}{l}\text { Seminal work analysing the relationship between dental morphology and } \\
\text { genetics among indigenous American populations }\end{array}$ \\
\hline Turner et al. 1991 & Extension to the standardization process begun by Washburn \\
\hline Scott and Turner 1997 & A classic work describing the study of dental morphology \\
\hline
\end{tabular}

Tab. 1 Short description of works that have shaped the study of dental non-metrics

57 Turner et al. 1991.

58 DAhLBERG 1951; 1956. Variation in trait expression was demonstrated even further, first by SCOTT and TuRnER (1997) with more elaborate descriptions and photographs, and recently by ScOTT and IrISH (2017) with a publication mostly consisting of photos of various degrees of trait expressions.

59 Hanihara 1992; Hubbard et al. 2015; Irish 1993; Larsen 1997; SCOTt 1973; SCOtT and TurNer 1997.
Once traits have been collected, Kendall's tau-b correlation coefficient is used to measure rank correlation between traits. Cases that show high correlations or low group sizes (less than ten cases)

60 NiCHOL 1990; IRISH 2005.

61 E.g., HaUessler et al. 1988.

62 IRISH 2005. 


\begin{tabular}{|c|c|}
\hline \multicolumn{2}{|l|}{ ASUDAS traits } \\
\hline WINGING UI1 & Enamel extensions UM1 \\
\hline LABIAL CONVEXITY UI1 & Root number UP1 \\
\hline Palatine torus & Root number UM2 \\
\hline ShOVELLING UI1 & Congenital absence UM3 \\
\hline Double-SHOVELLING UI1 & Odontome P1-2 \\
\hline PEG-SHAPED INCISOR UI2 & Lingual cusp number LP2 \\
\hline INTERRUPTION GROOVES UI2 & Anterior fovea LM1 \\
\hline TuBERCULUM DENTALE UI2 & Mandibular torus \\
\hline BuSHMAN CANINE UC & Groove pattern LM2 \\
\hline Distal accessory ridge UC & Rocker jaw \\
\hline Mesial and distal accessory ridges UP2 & Cusp 5 (hypoconulid) LM1 \\
\hline Mesial and distal accessory cusp UP1 & Cusp 6 LM1 \\
\hline Uto-Aztecan premolar UP1 & Cusp 7 LM1 \\
\hline Metacone UM3 & Protostylid LM1 \\
\hline Hypocone UM2 & Deflecting wrinkle LM1 \\
\hline Bifurcated hypocone UM2 & Mesial and distal trigonid crest LM1 \\
\hline Cusp 5 UM1 & Tome's root LP1 \\
\hline Marginal ridge tubercles UM1 & Root number LC \\
\hline Carabelli cusp UM1 & Root number LM1 \\
\hline Parastyle UM3 & Torsomolar angle LM2 \\
\hline
\end{tabular}

Tab. 2 ASUDAS traits

are removed from further analysis along with any traits that do not appear to carry any information across all the samples (i.e., traits that are common within all groups or completely absent in all groups). The remaining trait scores are dichotomized into present/absent according to thresholds established by previous studies, eliminating noise for further multivariate statistical analysis. ${ }^{63}$

The most commonly used method is the C.A.B. Smith's modified mean measure of divergence (MMD). ${ }^{64}$ MMD uses summary data to compare trait frequencies across groups, allowing it to cope with

63 Scott 1973; Turner 1985; 1987; Nichol 1990; SJøvold 1977.

64 Sмітн 1972. missing data. The distance statistic has been used in both dental ${ }^{65}$ and skeletal non-metric trait analysis. ${ }^{66}$ To establish statistically significant differences between groups, an MMD value twice the value of the standard deviation has been suggested. ${ }^{67}$ Patterns can be visualized with multidimensional scaling (MDS), which creates a spatial representation of 1-to$\mathrm{n}$ dimensions. Due to the high number of variables, causing the data to behave as it was continuous, an interval-level MDS (usually meant for continuous/

65 Irish 1998; 2003; 2005; Hanihara 1992; 2008; Ullinger et al. 2005.

66 E.g., see BERry and BERRY 1967, where MMD was used for the first time.

67 IrISH 2006. 


\begin{tabular}{|c|c|c|c|c|}
\hline Reference & Location & Dating & $\mathbf{N}$ & Description \\
\hline Roler 1982 & $\begin{array}{l}\text { 'Ain Ghazal, Wadi } \\
\text { Shu'eib, Bab edh- } \\
\text { Dhra', modern Lejjun }\end{array}$ & $\begin{array}{l}6600 \\
\text { BCE- } \\
\text { modern }\end{array}$ & 121 & $\begin{array}{l}\text { Though some studies had been pu- } \\
\text { blished prior to modern standards, } \\
\text { Bab edh-Dhra' showed biological } \\
\text { similarity to Mirgissa and Tall Sukas }\end{array}$ \\
\hline Bentley 1987 & Bab edh-Dhra ${ }^{c}$ & $\begin{array}{l}3150- \\
3050 \\
\mathrm{BCE}\end{array}$ & c. 300 & $\begin{array}{l}\text { Dental traits clustered by chamber, } \\
\text { suggesting tombs were shared by } \\
\text { family members }\end{array}$ \\
\hline MacCHIARELLI 1989 & Ra’s el-Hamra & $\begin{array}{l}\text { 5th-4th } \\
\text { millennia } \\
\text { BCE }\end{array}$ & 49 & $\begin{array}{l}\text { The within-group variation suggests } \\
\text { a prolonged period of genetic isola- } \\
\text { tion, leading to micro-differentiati- } \\
\text { on; the number of observable traits } \\
\text { was not high enough for comparati- } \\
\text { ve statistical analysis }\end{array}$ \\
\hline IRISH 1998 & Africa & $\begin{array}{l}10000 \\
\text { BCE- } \\
\text { modern }\end{array}$ & 1643 & $\begin{array}{l}\text { Significant differences between } \\
\text { North African and sub-Saharan sam- } \\
\text { ples. North Africans appear most } \\
\text { like Europeans and possibly Western } \\
\text { Asians }\end{array}$ \\
\hline PARRAS 2004 & $\begin{array}{l}\text { Souskiou-Vathyrkak- } \\
\text { as, Lemba-Lakkous, } \\
\text { Kissonerga-Mosphil- } \\
\text { ia, Enkomi, Ayios Ia- } \\
\text { kovos, Lerna, Asine, } \\
\text { Jerablus-Tahtani (JT) }\end{array}$ & $\begin{array}{l}3500- \\
2400 \\
\mathrm{BCE}\end{array}$ & $\begin{array}{l}\text { JT c. } 123 \\
\text { (total } \\
786)\end{array}$ & $\begin{array}{l}\text { Comparison of Chalcolithic and } \\
\text { Middle Bronze sites. Southwestern } \\
\text { Cypriot sites share close biological } \\
\text { affinities to one another and some } \\
\text { similarities with the Early Bronze } \\
\text { Syrian site }\end{array}$ \\
\hline $\begin{array}{l}\text { ULLINGER ET AL. } \\
2005\end{array}$ & Lachish, Dothan & $\begin{array}{c}4000- \\
332 \mathrm{BCE}\end{array}$ & 942 & $\begin{array}{l}\text { Results indicate biological conti- } \\
\text { nuity between the Bronze and Iron } \\
\text { Ages; Lachish is more homogenous } \\
\text { than Dothan, suggesting the latter } \\
\text { received a larger influx of people } \\
\text { from the Mediterranean }\end{array}$ \\
\hline IRISH 2006 & Egypt & $\begin{array}{l}\text { Pre- } \\
\text { dynastic- } \\
\text { Ptolemaic }\end{array}$ & 996 & $\begin{array}{l}\text { Overall homogeneity suggesting } \\
\text { population continuity; the distinc- } \\
\text { tiveness of the Lisht population } \\
\text { could be exclusive marriage practi- } \\
\text { ces among the (potentially Upper } \\
\text { Egyptian) group or genetic drift }\end{array}$ \\
\hline $\begin{array}{l}\text { LOVELL AND HADDOW } \\
2006\end{array}$ & Tell Leilan & $\begin{array}{l}2500 \\
\mathrm{BCE}\end{array}$ & 21 & $\begin{array}{l}\text { The intramural burials share fre- } \\
\text { quencies with other Canaanite sam- } \\
\text { ples, though results are tentative due } \\
\text { to the small sample size }\end{array}$ \\
\hline NASSAR 2010 & Mari & $\begin{array}{l}2950- \\
1760 \\
\text { BCE }\end{array}$ & $\begin{array}{c}\text { c. } 30 \\
\text { (total c. } \\
300)\end{array}$ & $\begin{array}{l}\text { Neither dental nor metric and non- } \\
\text { metric skeletal analyses revealed } \\
\text { differences within the site (oc- } \\
\text { cupation continuum) or between } \\
\text { Mari and Tell Leilan and Jerablus- } \\
\text { Tahtani }\end{array}$ \\
\hline Elias 2016 & Beirut and Batroun & $\begin{array}{c}1-300 \\
\mathrm{CE}\end{array}$ & 213 & $\begin{array}{l}\text { Variation was detected between } \\
\text { sexes, and age groups, as well as } \\
\text { between phases, reflecting the city's } \\
\text { history as a Roman colony }\end{array}$ \\
\hline
\end{tabular}

Tab. 3 Biodistance studies on Western Asian and ancient Egyptian populations using ASUDAS 


\begin{tabular}{|c|c|c|c|c|c|}
\hline Phase & Str. & Dyn. & MB phase & $\begin{array}{l}\text { Changes in occupation and mate- } \\
\text { rial culture }\end{array}$ & Orientation of tombs \\
\hline 1 & G & 13 th & MB IIA & $\begin{array}{l}\text { Settlement area with tombs const- } \\
\text { ructed nearby or in domestic cour- } \\
\text { tyards. Donkey burials, toggle pins } \\
\text { and weapon burials appear. }\end{array}$ & No pattern \\
\hline 2 & $\mathrm{~F}$ & 13 th & MB IIA-B & $\begin{array}{l}\text { The area is redistributed and parti- } \\
\text { ally sectioned into plots. The temple } \\
\text { precinct becomes prominent with } \\
\text { Temple III in the centre with smaller } \\
\text { north-eastern oriented structures } \\
\text { and Egyptian mortuary chapels built } \\
\text { around it. Cemeteries are moved to } \\
\text { the margins of the area. }\end{array}$ & $\begin{array}{l}\text { Aligned with Temple III either } \\
\text { south-south-east or south-east; } \\
\text { very little variation }\end{array}$ \\
\hline 2 & $\mathrm{E} / 3$ & 13th & MB IIB & & \multirow{5}{*}{$\begin{array}{l}\text { Greater flexibility but little } \\
\text { change }\end{array}$} \\
\hline $2-3$ & $\mathrm{E} / 2$ & & MB IIB & & \\
\hline 3 & $\mathrm{E} / 1$ & 14 th & MB IIB & $\begin{array}{l}\text { Living quarters are expanded over } \\
\text { tombs and chapels; the plots stay the } \\
\text { same (same owners). New eastern } \\
\text { Delta material culture emerges and } \\
\text { the amount of Cypriot imports incre- } \\
\text { ases. Weapons change from copper } \\
\text { to bronze and begin to disappear } \\
\text { from funerary deposits (this does not } \\
\text { happen in the rest of Levant until the } \\
\text { Late Bronze Age). }\end{array}$ & \\
\hline 3 & $\mathrm{D} / 3$ & 14 th & MB IIC & & \\
\hline 4 & $\mathrm{D} / 2$ & 15 th & MB IIC & $\begin{array}{l}\text { New tomb architecture (large shaft } \\
\text { tombs connected to house architec- } \\
\text { ture with both men and women, } \\
\text { perhaps family tombs). Very little to } \\
\text { no Syro-Palestinian imports; instead, } \\
\text { concentration is on Cypriot imports. } \\
\text { Weapons have disappeared from } \\
\text { burials. }\end{array}$ & \\
\hline
\end{tabular}

Tab. 4 Tell el-Dab ca Area A/II phases with corresponding strata (Str.), pharaonic dynasties (Dyn.) and Levantine Middle Bronze (MB) phases ${ }^{68}$

metric data) should be used. ${ }^{69}$ Correspondence Analysis (CA) ${ }^{70}$ a form of principal component analysis, can be used to measure variation among samples. It creates a chi-square distance matrix of the discrete data, revealing the variables that explain most of the variation. The visualization of CA values is very close to the MDS diagram. ${ }^{71}$

68 FORSTNER-MÜLLER 2010, 127-129.

69 IRISH 2005; 2006.

70 BenZÉCRI 1973; HirsCHFELd 1935.

71 IRISH 2006.
Despite its popularity in many craniometric studies, the Mahalanobis distance measure $\left(D^{2}\right)^{72}$ has not gained the same level of popularity as MMD, though it has some appealing advantages. $\mathrm{D}^{2}$ calculates weighted average correlations for each sample, which means it is not crippled by the effects of small sample sizes and it can account for any potential residual inter-trait correlation. But, because the weighted correlations are generated by calculating correlations

72 Mahalanobis 1927. 
in each sample and then pooling the results using group sizes, $\mathrm{D}^{2}$ cannot cope with missing data like MMD. ${ }^{73}$ It has also been noted that distance measures are usually correlated and give very simil9,5

Dental non-metric trait analysis has proven useful in studies considering variation in palaeontological, ${ }^{74}$ archaeological and modern settings. Table 3 contains studies that have been conducted on Western Asiatic and ancient Egyptian material using the ASUDAS (eliminating studies that do not follow the current standards). The increasing volume of research in the eastern Delta ${ }^{75}$ and across Western Asia has expanded the Bronze Age networks using a wide spectrum of material evidence. However, aside from a few biodistance analyses, skeletal evidence has remained mostly poorly utilized in these investigations. This is partially due to practical and methodological challenges, as biodistance analyses relying on morphology require large enough sample sizes (circa ten per group) with little destruction to the observable element.

\section{Analysing Tell el-Dab ${ }^{c} a$}

To study the Hyksos migration patterns, human skeletal remains from the Hyksos capital Avaris are analysed and compared with skeletal remains from the eastern Mediterranean and Western Asia. The majority of currently available Hyksos skeletal material was excavated during 1966-1969 and 1975-1980 in Tell el-Dab a Area A/II. ${ }^{76}$

The temples and burials seen in A/II combine to create a mixture of Egyptian and Near Eastern traditions $^{77}$ with gradual diachronic development before forming the unique eastern Delta culture visible in the later phases (Tab. 4). Phase 3 is marked by the appearance of a distinctive Delta material culture that exhibits both Egyptian and Levantine traditions, and even further changes can be observed from the funerary evidence in Phase $4{ }^{78}$ The most notable features of continuation, however, are Temple III, used from the late $13^{\text {th }}$ to the early $18^{\text {th }}$ Dynasty, and the land plots that appear to have remained unchanged throughout the period..$^{79}$

Winkler and Wilfing conducted an osteological analysis on the human remains, recording age, sex and ancestry, as well as dental, cranial and post-cranial

73 IRISH 2010.

74 E.g., Edgar 2002; Gómez-Robles et al. 2012; GuatelliSteinberg and Irish 2005; Hanihara 2008; MartinÓNTorres et al. 2007; SCOTt and Turner 1997.

75 Bietak 1996; Forstner-Müller 2010; Forstner-Müller et al. 2015; Holladay 1982; Redmount 2000; RzePKa et al. 2009.

76 WinkLER and WILFING 1991.

$77 \mathrm{Cf}$. BietaK in this volume.

78 Cf. PreLl in this volume.

79 Forstner-Müller 2010, 127-129. metric and non-metric information. ${ }^{80}$ The results pointed to a population of poor health with a low life expectancy at birth. A hierarchical cluster analysis on craniometry separated the Tell el-Dab'a males from the females, tying them more closely to the Levantine area and especially to the individuals in the Iron Age cemetery of Kamid el-Loz. ${ }^{81}$ This implies that immigration followed uxorilocal activity, with males moving into the area and forming relationships with local females, which was a common custom among mercenaries and sailors at the time. ${ }^{82}$

The Tell el-Dab a skeletal report and the official ASUDAS standard were published in the same year. Therefore, the dental non-metric data recorded by Winkler and Wilfing could not have followed the grades of the current standard, and the list of traits is not as comprehensive. The original analysis is now expanded on by employing ASUDAS, and the data are processed using a suite of statistical tools (mentioned in the previous section) and considered in light of ethnogenesis theory, kinship and, ultimately, large-scale migration patterns. Before asking any question about the Hyksos provenance, the intra-site dynamics of Tell el-Dab a must be understood. Were the Hyksos, in fact, a biologically homogenous group, or was unity formulated through other factors?

\section{Discussion and Conclusions}

Early scholarship relied heavily on textual evidence produced by contemporary outsiders and much later historians, whilst more recent archaeological research has produced contradicting evidence, especially against the accounts given by Manetho. The gradual development of Avaris and the changes visible in the archaeological record generate a mixture of material culture from sites across the eastern Mediterranean, potentially of several origins, raising the question of the use of a single denominator.

The study of Hyksos provenance and identity is part of the current trend in archaeological research of pursuing a view of the past that considers all facets of human existence. Interpretations have moved away from unilinear descriptions to interpretations where humans are regarded as a dynamic part of the environment and the surrounding community, both culturally and biologically.

Non-destructive biodistance analysis using macroscopic methods can be of great value where other techniques are not available due to access or preservation circumstances. Though the success of current research in its endeavour to move away from old conventions has been questioned in bioanthropology, ${ }^{83}$ the ongoing development of

80 WiNKLER and WILFING 1991.

81 Winkler and Wilfing 1991, 95.

82 Bietak 1996, 35-36.

83 Armelagos and Van Gerven 2003. 
methodology and clarification of theory argues against stagnation. ${ }^{84}$ Current biodistance analyses have the awareness to reject preconditioning models and instead focus on other factors, such as preferring geographic distance to culturally constructed affiliation. Ethnogenesis theory has created a framework that improves the understanding of kinship patterns that do not rely solely on biological closeness. By changing scale, biodistance analysis can generate intra-site studies that build into patterns of migration and mobility 'from the ground up'. ${ }^{85}$

\section{Acknowledgements}

Research Track 7 of the Hyksos Enigma Project thanks the ICAANE workshop organizers, Manfred Bietak and Silvia Prell, as well as all the speakers who contributed to the workshop.

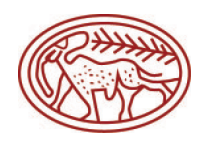

"This project has received funding from the European Research Council (ERC) under the European Union's Horizon 2020 research and innovation programme (grant agreement no. 668640)" 


\section{Bibliography}

ADAMS, W.Y.

1968 Invasion, Diffusion, Evolution? Antiquity 42, 194215.

Adams, W.Y., Van Gerven, D.P. and Levy, R.S.

1978 The Retreat from Migrationism, Annual Review of Anthropology 7, 483-532.

Alt, A.

1954 Die Herkunft der Hyksos in neuer Sicht, Berlin.

ANTHONY, D.W.

1990 Migration in Archaeology: The Baby and the Bathwater, American Anthropologist 92, 895-914.

Armelagos, G.J., Carlson, D.S. and Van Gerven, D.P.

1982 The Theoretical Foundations and Development of Skeletal Biology, in: F. Spencer (ed.), A History of American Physical Anthropology, New York, 305328.

Armelagos, G.J. and Van Gerven, D.P.

2003 A Century of Skeletal Biology and Paleopathology: Contrasts, Contradictions, and Conflicts, American Anthropologist 105, 53-64.

Azoulay, L. and Regnault, F.

1893 Des diverses formes des dents incisives supérieures. Bulletins et Mémoires de la Société d'Anthropologie de Paris 16, 266-269.

BADER, B.

2008 Avaris and Memphis in the Second Intermediate Period in Egypt (ca. 1770-1550/40 B.C.), in: J.M. Córdoba, M. Molist, M.C. Pérez, I. Rubio and S. Martinez (eds.), Proceedings of the $5^{\text {th }}$ International Congress on the Archaeology of the Ancient Near East, Madrid.

2012 Migration in Archaeology: An Overview with a Focus on Ancient Egypt, in: M. Messer, R. Schroeder and R. Wodak (eds.), Migrations: Interdisciplinary Perspectives, Vienna, 213-226.

BARTH, F.

1969 Ethnic Groups and Boundaries: The Social Organization of Culture Difference, London.

BECKERATH, J. VON

1964 Untersuchungen zur politischen Geschichte der Zweiten Zwischenzeit in Ägypten, Glückstadt.

Bentley, G

1987 Kinship and Social Structure at Early Bronze IA Bab edh-Dhrac, Jordan, PhD Dissertation, University of Chicago, Chicago.

BENZÉCRI, J.P.

1973 L’Analyse des données, Paris.

Berry, A. and Berry, R.

1967 Epigenetic Variation in the Human Cranium, Journal of Anatomy 101, 361-379.

BietaK, M.

1996 Avaris: The Capital of the Hyksos. Recent Excavations at Tell el-Dab ${ }^{c} a$, London.

2003 Two Ancient Near Eastern Temples with Bent Axis in the Eastern Nile Delta, Egypt and the Levant 13, 13-38.

BINFORD, L.

1965 Archaeological Systematics and the Study of Culture Process, American Antiquity 31.2.1, 203-210.

BlumenBaCH, J.F.

1775 De Generis humani varietate nativa liber, Göttingen.

BOURRIAU, J.

2010 The Relative Chronology of the Second Intermediate Period: Problems in Linking Regional Archaeological Sequences, in: M. MArÉE (ed.), The Second Intermediate Period (Thirteenth-Seventeenth Dynasties): Current Research, Future Prospects, Orientalia Lovaniensia Analecta 192, Leuven, Paris, Dudley, 11-38.

Buikstra, J.E.

1977 Biocultural Dimensions of Archaeological Study: A Regional Perspective, in: R. Blakely (ed.), Biocultural Adaptation in Prehistoric America, Athens.

Buikstra, J.E., Frankenberg, S.R. and Konigsberg, L.W.

1990 Skeletal Biological Distance Studies in American Physical Anthropology: Recent Trends, American Journal of Physical Anthropology 82, 1-7.

Burmeister, S.

2000 Archaeology and Migration: Approaches to an Archaeological Proof of Migration, Current Anthropology 41, 539-567.

Carabelli, G.

1842 Systematisches Handbuch der Zahnheilkunde, Wien.

Cavalli-Sforza, L.L., Menozzi, P. and Piazza, A.

1994 The History and Geography of Human Gene, Princeton.

Clark, G.

1972 Star Carr: A Case Study in Bioarchaeology, New York.

Collier, J.F. and Yanagisako, S.J. (eds.)

1987 Gender and Kinship: Essays toward a Unified Analysis, Stanford.

Connerton, $\mathrm{P}$

1989 How Societies Remember, Cambridge.

DAhlberG, A.A.

1956 Materials for the Establishment of Standards of Tooth Characteristics, Attributes and Techniques in Morphological Studies of the Dentition, Chicago. 
1951 The Dentition of the American Indian, in: W.S. Laughuin (ed.), Papers on the Physical Anthropology of the American Indian, New York, 138-176.

Dommelen, P. VAN

2014 Moving On: Archaeological Perspectives on Mobility and Migration, World Archaeology 46, 477-483.

EDGAR, H.J.H.

2002 Biological Distance and the African American Dentition, Columbus.

Elias, N.

2016 Pratiques funéraires et identités biologiques à Berytus et à Botrys à l'époque romaine (Liban, Ier siècle av. J.-C. - IVème siècle apr. J.-C.), archéologie et préhistoire, $\mathrm{PhD}$ Dissertation, Université de Bordeaux, Bordeaux.

ENGBERG, R.M.

1939 The Hyksos Reconsidered, Studies in Ancient Oriental Civilization 18, Chicago.

Flinders Petrie, W.M.

1906 Hyksos and Israelite Cities, London.

FLOWER, H.W

1885 On the Size of the Teeth as a Character of Race, Journal of the Anthropological Institute of Great Britain and Ireland 14, 183-187.

FORSTNER-MÜLLER, I.

2010 Tombs and Burial Customs at Tell el-Dab ${ }^{`}$ a during the Late Middle Kingdom and the Second Intermediate Period, in: M. Marée (ed.), The Second Intermediate Period (Thirteenth-Seventeenth Dynasties): Current research, Future Prospects, Orientalia Lovaniensia Analecta 192, Leuven, Paris, Dudley, 127-138.

Forstner-Müller, I., Jeuthe, C., Michel, V. and Prell, S.

2015 Grabungen des Österreichischen Archäologischen Instituts Kairo in Tell el-Dab a/Avaris, Egypt and the Levant 25, 17-71.

GARDINER, A.H.

1916 The Defeat of the Hyksos by Kamōse: The Carnarvon Tablet, No. I, Journal of Egyptian Archaeology $3,95-110$.

Gardiner, A.H. and Peet, T.E.

1955 The Inscriptions of Sinai, London.

Greenblatt, S.

2010 Cultural Mobility, Cambridge.

GRIFFITH, F.L.

1897 Hieratic Papyri from Kahun and Gurob, London.

Guatelli-Steinberg, D. and Irish, J.D.

2005 Brief Communication: Early Hominin Variability in First Molar Dental Trait Frequencies, American Journal of Physical Anthropology 128, $477-484$.
Haber, M., Doumet-Serhal, C., Scheib, C., Xue, Y., Danecek, P., Mezzavilla, M., Youhanna, S., Martiniano, R., Prado-Martinez, J., Szpak, M., Matisoo-Smith, E., Schutkowski, H., Mikulski, R., Zalloua, P., Kivisild, T. and TYler-Smith, C.

2017 Continuity and Admixture in the Last Five Millennia of Levantine History from Ancient Canaanite and Present-Day Lebanese Genome Sequences, American Journal of Human Genetics 101, 274-282.

HaKenBeck, S.

2008 Migration in Archaeology: Are We Nearly There Yet? Archaeological Review from Cambridge 23, 9-26.

Hanihara, K.

1954 Studies on the Deciduous Dentition of the Japanese and the Japanese-American Hybrids. I. Deciduous Incisors, Journal of the Anthropological Society of Nippon 63, 168-185.

1955 Studies on the Deciduous Dentition of the Japanese and the Japanese-American Hybrids. II. Deciduous Canines, Journal of the Anthropological Society of Nippon 64, 63-82.

HaNiHARA, T.

1992 Dental and Cranial Affinities among Populations of East Asia and the Pacific: The Basic Populations in East Asia, IV, American Journal of Physical Anthropology 88, 163-182.

2008 Morphological Variation of Major Human Populations Based on Nonmetric Dental Traits, American Journal of Physical Anthropology 136, 169-182.

Hawass, Z., Gad, Y.Z., Ismail, S., Khairat, R., Fathalla, D., Hasan, N., Ahmed, A., Elleithy, H., Ball, M., Gaballah, F., Wasef, S., Fateen, M., Amer, H., Gostner, P., Selim, A., Zink, A. and Pusch, C.M.

2010 Ancestry and Pathology in King Tutankhamun's Family, Journal of the American Medical Association 303, 638-647.

Hawass, Z., Ismail, S., Selim, A., Saleem, S.N., Fathalla, D., Wasef, S., Gad, A.Z., SaAd, R., Fares, S., Amer, H., Gostner, P., Gad, Y.Z., Pusch, C.M. and Zink, A.R.

2012 Revisiting the Harem Conspiracy and Death of Ramesses III: Anthropological, Forensic, Radiological, and Genetic Study, British Medical Journal 345, <https://www.bmj.com/content/345/bmj. e8268> (last access 19 July 2019)

Hefner, J.T., Pilloud, M.A., Buikstra Jane, E. and VogelsBERG, C.C.M.

2016 A Brief History of Biological Distance Analysis, in: M.A. Pilloud and T. Hefner Joseph (eds.), Biological Distance Analysis: Forensic and Bioarchaeological Perspectives, London, 3-22.

Helck, H.

1971 Die Beziehungen Ägyptens zu Vorderasien im 3. und 2 Jahrtausend v. Chr., $2^{\text {nd }}$ edition, Wiesbaden. 
HIRSCHFELD, H.O.

1935 A Connection between Correlation and Contingency, Proceedings of the Cambridge Philosophical Society $31,520-524$.

HOLLADAY, J.S.

1982 Tell el-Maskhuta: Preliminary Report on the Wadi Tumilat Project 1978-1979, Malibu.

HrdLIČKa, A.

1920 Shovel-Shaped Teeth, American Journal of Physical Anthropology 3.4, 429-465.

1921 Further Studies of Tooth Morphology, American Journal of Physical Anthropology 4.3, 141-176.

Hubbard, A.R., Guatelli-Steinberg, D. and Irish, J.D.

2015 Do Nuclear DNA and Dental Nonmetric Data Produce Similar Reconstructions of Regional Population History? An Example from Modern Coastal Kenya, American Journal of Physical Anthropology $157,295-304$.

IRISH, J.D.

1993 Biological Affinities of Late Pleistocene through Modern African Aboriginal Populations: The Dental Evidence, PhD Dissertation, Arizona State University, Tempe.

1998 Dental Morphological Affinities of Late Pleistocene through Recent Sub-Saharan and North African Peoples, Bulletins et mémoires de la Société d'anthropologie de Paris 10, 237-272.

2005 Population Continuity vs. Discontinuity Revisited: Dental Affinities among Late Paleolithic through Christian Era Nubians, American Journal of Physical Anthropology 128, 520-535.

2006 Who Were the Ancient Egyptians? Dental Affinities among Neolithic through Postdynastic Peoples, American Journal of Physical Anthropology 129, 529-543.

2010 The Mean Measure of Divergence: Its Utility in Model-Free and Model-Bound Analyses Relative to the Mahalanobis D-2 Distance for Nonmetric Traits, American Journal of Human Biology 22, 378-395.

IRISH, J.D. and FRIEDMAN, R.

2010 Dental Affinities of the C-group Inhabitants of Hierakonpolis, Egypt: Nubian, Egyptian, or Both? HOMO, Journal of Comparative Human Biology 61, 81-101.

Irish, J.D. and Guatelli-Steinberg, D.

2003 Ancient Teeth and Modern Human Origins: An Expanded Comparison of African Plio-Pleistocene and Recent World Dental Samples Article, Journal of Human Evolution 45, 113-144.

Johnson, K.M. and PAul, K.S.

2016 Bioarchaeology and Kinship: Integrating Theory, Social Relatedness, and Biology in Ancient Family Research, Journal of Archaeological Research 24, $75-123$.

Keller, A., Graefen, A., Ball, M., Matzas, M., Boisguerin, V., Maixner, F., Leidinger, P., Backes, C., Khairat, R., Forster, M., Stade, B., Franke, A., Mayer, J., Spangler, J.,
McLaughlin, S., Shah, M., Lee, C., Harkins, T.T., Sartori, A Moreno-Estrada, A., Henn, B., Sikora, M., Semino, O., Chiaroni, J., Rootsi, S., Myres, N.M., CAbrera, V.M., Underhill, P.A., Bustamante, C.D., Vigl, E.E., Samadelli, M., Cipollini, G., Haas, J., Katus, H., O'Connor, B.D., Carlson, M.R. Meder, B., Buin, N., Meese, E., Pusch, C.M. and ZinK, A.

2012 New Insights into the Tyrolean Iceman's Origin and Phenotype as Inferred by Whole-Genome Sequencing, Nature Communications 3, 698.

KELLY, R.L.

1992 Mobility/Sedentism: Concepts, Archaeological Measures, and Effects, Annual Review of Anthropology 21, 43-66.

Killgrove, K.

2013 Bioarchaeology, in: J.L. JACKSON, JR. (ed.), Oxford Bibliographies Online - Anthropology, http://www. oxfordbibliographies.com/abstract/document/obo9780199766567/obo-9780199766567-0121.xml?rskey $=\mathrm{Va} 4 \mathrm{vCj} \&$ result $=7$ (last access 19 July 2019)

KONIGSBERG, L.W.

2006 A Post-Neumann History of Biological and Genetic Distance Studies in Bioarchaeology, in: J.E. BUIKSTRA and L.A. BECK (eds.), Bioarchaeology: The Contextual Analysis of Human Remains, Amsterdam, 263-280.

Kossinna, G.

1911 Die Herkunft der Germanen, Leipzig.

LABIB, P.C.

1936 Die Herrschaft der Hyksos in Ägypten und ihr Sturz, Glückstadt.

LARSEN, C.S.

1997 Bioarchaeology: Interpreting Behavior from the Human Skeleton, New York.

1987 Bioarchaeological Interpretations of Subsistence Economy and Behavior from Human Skeletal Remains, in: M.B. Schiffer (ed.), Advances in Archaeological Method and Theory, San Diego, 339-445.

LASKER, G.W.

1945 Observations on the Teeth of Chinese Born and Reared in China and America, American Journal of Physical Anthropology 3, 129-150.

Lévi-Strauss, C.

1952 Race and History, Paris.

Linnaeus, C

1735 Systema naturae, Leiden.

1758 Systema naturae per regna tria naturae, secundum classes, ordines, genera, species, cum characteribus, differentiis, synonymis, locis, $10^{\text {th }}$ edition, Stockholm.

LOPRIENO, A

1988 Topos und Mimesis: zum Ausländer in der ägyptischen Literatur, Wiesbaden.

Lovell, N.D. and HadDow, S.

2006 Nonmetric Traits on Permanent Dentition from Bronze Age Tell Leilan, Syria, International Journal of Dental Anthropology 11, 1-21. 
LuFT, U.

1992 Asiatics in Illahun: A Preliminary Report, in: EDITOR, Atti Sesto Congresso Internationale di Egittologia. Atti, volume II, Torino, 291-297.

Macchiarelli, R.

1989 Prehistoric "Fish-Eaters" along the Eastern Arabian Coasts: Dental Variation, Morphology, and Oral Health in the Ra's al-Hamra Community (Qurum, Sultanate of Oman, $5^{\text {th }}-4^{\text {th }}$ Millennia BC), American Journal of Physical Anthropology 78, 575-594.

MaCcormack, C. and Strathem, M. (eds.)

1980 Nature, Culture, and Gender, Cambridge.

Mahalanobis, P.C.

1927 Analysis of Race Mixture in Bengal, Journal of the Asiatic Society of Bengal 23, 301-333.

MARKS, J.

1995 Human Biodiversity: Genes, Race and History, New York.

MASPERo, G.

1903 History of Egypt, Chaldea, Syria, Babylonia, and Assyria, London.

Mikels-Carrasco, J.

2012 Sherwood Washburn's New Physical Anthropology: Rejecting the "Religion of Taxonomy", History and Philosophy of the Life Sciences 34, 79-101.

Moore, J.H.

1994 Putting Anthropology Back Together Again: The Ethnogenetic Critique of Cladistic Theory, American Anthropologist 96, 925-948.

Moorrees, C.F

1957 The Aleut Dentition: A Correlative Study of Dental Characteristics in an Eskimoid People, Cambridge, MA.

Morton, S.G.

1844 Crania Aegyptiaca, Philadelphia.

Myhre, B.M. and Myhre, B.

1972 The Concept 'Immigration' in Archaeological Contexts Illustrated by Examples from West Norwegian and North Norwegian Early Iron Age, Norwegian Archaeological Review 5, 45-70.

NASSAR, J.

2010 Les espaces funéraires infra-urbains de Mari (Moyen-Euphrate, 2900-1760 AV.J.-C.), analyse archéo-anthropologique, PhD Dissertation, Lebanese University, Beirut.

Newberry, P.E.

1893 Beni Hasan, London.

NiCHOL, C.R.

1990 Dental Genetics and Biological Relationships of the Pima Indians of Arizona, PhD Dissertation, Arizona State University, Tempe.
Owen, R.

1840 Odontography; or, a Treatise on the Comparative Anatomy of the Teeth; Their Physiological Relations, Mode of Development, and Microscopic Structure, in the Vertebrate Animals, London.

Parras, $Z$.

2004 The Biological Affinities of the Eastern Mediterranean in the Chalcolithic and Bronze Age: A Regional Dental Non-metric Approach, PhD Dissertation, University of Sheffield, Sheffield.

Redmount, C

2000 On an Egyptian/Asiatic Frontier, Vol. 3, PhD Dissertation, University of Chicago, Chicago.

RoLeR, K.L.

1992 Near Eastern Dental Variation: Past and Present, MA Thesis, Arizona State University, Tempe.

Rzepka, S., Wodzinska, A., Hudec, J. and Herbich, T.

2009 Tell el-Retaba 2007-2008, Egypt and the Levant 19, 241-280.

Schillaci, M.A., Irish, J.D. and Wood, C.C.

2009 Further Analysis of the Population History of Ancient Egyptians, American Journal of Physical Anthropology 139, 235-243.

SCHNEIDER, D.M.

1984 A Critique of the Study of Kinship, Ann Arbor.

1972 What Is Kinship All About? in: P. ReINING (ed.), Kinship Studies in the Morgan Centennial Year, Washington.

Schutkowski, H., Hansen, B., Wormuth, M. and Herrmann, B. 2001 Signatures of Stable Strontium (Sr) Isotopes in Human Hard Tissue: Utilisation in Osteological Identification, Research in Legal Medicine 26, $31-40$.

Schutrowski, H. and Ogden, A.

2011 Sidon of the Plain, Sidon of the Sea - Reflections on Middle Bronze Age Diet in the Eastern Mediterranean, Archaeology and History in the Lebanon 34-35, 213-225.

Scott, G. and Irish, J.

2017 Human Tooth Crown and Root Morphology: The Arizona State University Dental Anthropology System, Cambridge.

ScotT, G.R.

1973 Dental Morphology: A Genetic Study of American White Families and Variation in Living Southwest Indians, PhD Dissertation, Arizona State University, Tempe.

Scott, G.R. and Turner, C.G., II

1988 Dental Anthropology, Annual Review of Anthropology $17,99-126$.

1997 The Anthropology of Modern Human Teeth: Dental Morphology and Its Variation in Recent Human Populations, Cambridge. 
SJøvold, T.

1977 Non-metrical Divergence between Skeletal Populations, Ossa, International Journal of Skeletal Research 4, Supplement 1, Stockholm.

1973 The Occurrence of Minor Non-metrical Variants in the Skeleton and Their Quantitative Treatment for Population Comparison, HOMO, Journal of Comparative Human Biology 24, 204-233.

SMITH, C.A.B

1972 Coefficients of Biological Distance, Annals of Human Genetics 36, 241-245.

Soltysiak, A. and Bialon, M.

2013 Population History of the Middle Euphrates Valley: Dental Non-metric Traits at Tell Ashara, Tell Masaikh and Jebel Mashtale, Syria, HOMO, Journal of Comparative Human Biology 64, 341356.

SoŁtysiak, A. and SchutKowski, $\mathrm{H}$.

2015 Continuity and Change in Subsistence at Tell Barri, NE Syria, Journal of Archaeological Science: Reports $2,176-185$.

Stinson, S., Bogin, B. and O'Rourke, D.

2012 Human Biology: An Evolutionary and Biocultural Perspective, in: S. Stinson, B. Bogin and D. O'RoURKE (eds.), Human Biology: An Evolutionary and Biocultural Perspective, Hoboken, 1-22.

StoJANOWSKI, C.

2013 Ethnogenetic Theory and New Directions in Biodistance Research, in: C. LOZADA and B. O'Donnabhain (eds.), The Dead Tell Tales: Essays in Honor of Jane E. Buikstra, Los Angeles, 71-82.

Sturtevant, W

1971 Greek into Seminole, in: E.B. LeACOCK and N.O. LuRIE (eds.), North American Indians in Historical Perspective, New York, 92-108.

THOMPSON, A.

1903 Ethnographic Odontology: The Inca Peruvians, Tulsa.

ToMKINS, H.G

1890 Notes on the Hyksos or Shepherd Kings of Egypt, The Journal of the Anthropological Institute of Great Britain and Ireland 19, 182-199.

TRIGGER, B.G.

2006 A History of Archaeological Thought, Culture-Historical Archaeology, Cambridge.
TuRNER, C.G., II

1985 Expression Count: A Method for Calculating Morphological Dental Trait Frequencies by Using Adjustable Weighting Coefficients with Standard Ranked Scales, American Journal of Physical Anthropology 68, 263-267.

1987 Late Pleistocene and Holocene Population History of East Asia Based on Dental Variation, American Journal of Physical Anthropology 73, 305-321.

Turner, C.G., II, Nichol, C.R. and Scott, G.R.

1991 Scoring Procedures for Key Morphological Traits of the Permanent Dentition: The Arizona State University Dental Anthropology System, in: M.A. KelLey and C.S. Larsen (eds.), Advances in Dental Anthropology, New York, 13-32.

Ullinger, J. M., Sheridan, S. G., Hawkey, D. E., Turner, C. G., 2nd and COOLEY, R.

2005. Bioarchaeological analysis of cultural transition in the southern Levant using dental nonmetric traits. American Journal of Physical Anthropology 128 (2), 466-476.

VAn SETERs, J.

1966 The Hyksos: A New Investigation, New Haven.

WADDELL, W.G.

1940 Manetho, with an English Translation by W.G. Waddell, London.

WARD, W.A

1961 Egypt and the East Mediterranean in the Early Second Millennium B.C., Orientalia 30, 129-155.

Willey, G. and Phillips, P.

1958 Method and Theory in American Anthropology, Chicago.

WinkLer, E. and Wilfing, H.

1991 Tell el-Dab a VI: Anthropologische Untersuchungen an den Skelettresten der Kampagnen, Vienna.

ZAKRZEWSKI, S.R

2007 Population Continuity or Population Change: Formation of the Ancient Egyptian State, American Journal of Physical Anthropology 132, 501-509.

Zink, A.R., Grabner, W., Reischl, U., Wolf, H. and Nerlich, A.G. 2003 Molecular Study on Human Tuberculosis in Three Geographically Distinct and Time Delineated Populations from Ancient Egypt, Epidemiology and Infection 130, 239-249.

Zuckerman, M.K., Turner, B.L. and Armelagos, G.J.

2011 Evolutionary Thought in Paleopathology and the Rise of the Biocultural Approach, in: A.L. Grauer (ed.), $A$ Companion to Paleopathology, Hoboken, 34-57. 